\title{
DETERMINAN OPINI AUDIT GOING CONCERN (Studi Empiris Pada Perusahaan Real Estate dan Property yang Terdaftar di BEI Tahun 2013-2015)
}

\author{
Hafid Byusi ${ }^{1}$ \\ * Akuntansi, Fakultas Ekonomi dan Bisnis, Universitas Muhammadiyah Surakarta \\ *hafidbyusi@gmail.com ${ }^{1}$ \\ Fatchan Achyani ${ }^{2}$ \\ * Akuntansi, Fakultas Ekonomi dan Bisnis, Universitas Muhammadiyah Surakarta \\ *fa185@ums.ac.id ${ }^{2}$
}

\begin{abstract}
This research aims to analyze the influence of opinion shopping, corporate growth, liquidity, the proportion of independent commissioners and audit committee on acceptance of going concern audit opinion. The populations in this research are real estate and property companies listed in Indonesia Stock Exchange. Sampling was done by purposive sampling method and obtained 120 companies as a sample for the period 2013-2015. Data analysis technique used logistic regression analysis. The results of this research prove that liquidity has a significant effect on the acceptance of going concern audit opinion, while opinion shopping, company growth, the proportion of independent commissioners, and audit committee have no significant effect on the acceptance of going concern audit opinion.
\end{abstract}

Keywords: opinion shopping, company growth, liquidity, the proportion of independent commissioners, audit committee, going concern audit opinion.

\section{Pendahuluan}

Suatu entitas bisnis dalam menjalankan aktivitas bisnis perusahaan tentu selalu berupaya untuk tetap mempertahankan kelangsungan hidup (going concern) usahanya, di samping untuk mencapai tujuan utama, yaitu meningkatkan profitabilitas (Utama dan Verdiana, 2013). Kondisi perusahaan yang sehat akan lebih mendapatkan kepercayaan dari masyarakat luas dan investor khususnya jika didukung dengan audit independen (Nursari dan Maria, 2015).

Auditor independen akan memberikan opini atas hasil penilaian laporan keuangan sesuai dengan kondisi perusahaan sesungguhnya. Auditor juga bertanggungjawab untuk menilai apakah terdapat kesangsian besar terhadap kemampuan perusahaan dalam mempertahankan kelangsungan hidupnya (going concern) dalam periode waktu tidak lebih dari satu tahun sejak tanggal laporan audit (SPAP seksi 341, 2011). Kesangsian besar auditor terhadap kemampuan entitas dalam mempertahankan kelangsungan hidupnya mengharuskan auditor untuk mengkomunikasikan resiko kebangkrutan tersebut kepada Investor dan para pemakai laporan keuangan lainnya setelah dilakukan evaluasi terhadap rencana manajemen terlebih dahulu (Muttaqin dan Sudarno, 2012).

Sekar (2003) dalam Kartika (2012) menyatakan masalah timbul ketika banyak terjadi kesalahan opini (audite failures) yang dibuat oleh auditor menyangkut opini going concern. Beberapa penyebabnya antara lain, pertama adalah masalah self-fulfilling prophecy yang mengakibatkan auditor enggan mengungkapkan status going concern yang muncul ketika auditor khawatir bahwa opini going concern yang dikeluarkan dapat mempercepat kegagalan perusahaan yang bermasalah (Venuti, 2007) dalam Krissindiastuti dan Rasmini (2016). Meskipun demikian, opini going concern harus diungkapkan dengan harapan dapat mempercepat upaya penyelamatan perusahaan yang bermasalah. Masalah kedua yang menyebabkan kegagalan audit (Audit Failures) adalah tidak terdapatnya prosedur penetapan status going concern yang terstruktur (Joanna, 1994) dalam Debby dan Tandungan (2016).

Masalah going concern merupakan hal yang kompleks dan terus ada. Sehingga diperlukan faktor- 
faktor sebagai tolak ukur yang pasti untuk menentukan status going concern pada perusahaan. Dan faktorfaktor tersebut harus diuji agar dalam keadaan ekonomi yang fluktuatif, status going concern tetap dapat diprediksi (Muttaqin dan Sudarno, 2012). Beberapa faktor yang diduga mempengaruhi audit going concern antara lain: opinion shopping, pertumbuhan perusahaan, likuiditas, proporsi komisaris independen dan komite audit.

Hao et al (2011) dalam Utama dan Verdiana (2013) menyatakan penerbitan opini audit going concern akan menimbulkan dampak negatif pada perusahaan karena akan menyebabkan berkurangnya kepercayaan pemegang saham maupun investor terhadap perusahaan sehingga manajer akan cenderung menekan auditor untuk mengeluarkan opini wajar tanpa pengecualian. Opinion Shopping didefinisikan oleh SEC, sebagai aktifitas mencari auditor yang mau mendukung perlakuan akuntansi yang diajukan oleh manajemen untuk mencapai tujuan pelaporan perusahaan. Chen et al, (2005) dalam Nursari dan Maria (2015) dalam hasil penelitiannya menyatakan bahwa ketika perusahaan mengganti auditor (switching auditor), maka akan menurunkan kemungkinan mendapat opini audit yang tidak dikehendaki, dibandingkan dengan perusahaan yang tidak mengganti auditornya untuk beberapa periode. Jadi perusahaan yang berhasil melakukan opinion shopping, berharap mendapat unqualified opinion dari auditor yang baru.

Opini going concern yang diterima oleh suatu perusahaan menunjukkan adanya kondisi dan peristiwa yang menimbulkan keraguan auditor akan kelangsungan hidup perusahaan (Azizah dan Aniskurlillah, 2014). Salah satu hal yang perlu dipertimbangkan oleh seorang auditor dalam mengevaluasi laporan keuangan entitas untuk mengetahui adanya going concern adalah pertumbuhuhan perusahaan. Auditee yang mempunyai rasio per-tumbuhan penjualan yang positif mengindikasikan bahwa auditee dapat mempertahankan posisi ekonominya dan lebih dapat mempertahankan kelangsungan hidupnya (Kartika, 2012). Perusahaan yang mempunyai pertumbuhan yang baik dapat dilihat dengan pertambahan pendapatan atau revenue per tahunnya. Penjualan yang terus meningkat dari tahun ke tahun akan memberi peluang auditee untuk memperoleh peningkatan laba.
Semakin tinggi rasio pertumbuhan penjualan auditee, akan semakin kecil kemungkinan auditor untuk menerbitkan opini audit going concern (Krissindiastuti dan Rasmini, 2016). Perusahaan yang mempunyai pertumbuhan yang tinggi tidak akan mengalami kebangkrutan, sedangkan perusahaan dengan pertumbuhan kearah negatif menandakan kecenderungan perusahaan mengalami kebangkrutan menjadi besar (Petronela, 2004) dalam Sulistya dan Sukartha, (2013). Karena kebangkrutan merupakan salah satu dasar bagi auditor untuk memberikan opini audit going concern, maka perusahaan yang mengalami pertumbuhan perusahaan yang negatif akan makin tinggi kecenderungan untuk menerima opini going concern (Kartika, 2012).

Salah satu cara perusahaan dalam mempertahankan kelangsungan hidup kedepannya adalah dengan memperhatikan rasio likuiditas. Likuditas merupakan kemampuan perusahaan untuk membayar kewajiban jangka pendeknya. Likuiditas mengacu pada kemampuan perusahaan membiayai kewajibannya dilihat dari posisi keuangan secara keseluruhan serta dapat memberikan tanda awal mengenai masalah arus kas dan kegagalan usaha yang akan dihadapi perusahaan di masa akan datang karena tanda awal dari terjadinya kesulitan keuangan dan kebangkrutan adalah nilai likuiditas yang rendah atau menurun (Nurdin dkk, 2016). Dalam hubungannya dengan likuiditas makin kecil likuiditas, perusahaan kurang likuid sehingga tidak dapat membayar para krediturnya, maka akan timbul kemungkinan auditor memberikan opini audit dengan going concern (Melania dkk, 2016).

Penerapan prinsip-prinsip good corporate governance saat ini sangat diperlukan agar perusahaan dapat bertahan dan tangguh dalam menghadapi persaingan yang semakin ketat, serta agar dapat menerapkan etika bisnis secara konsisten sehingga dapat mewujudkan iklim usaha yang sehat, efisien, dan transparan (Eduk dan Nugraeni, 2015). Banyaknya krisis ekonomi yang terjadi saat ini dikarenakan manajemen tidak menerapkan good corporate governance dalam menjalakan kegitan usahanya. Penerapan good corporate governance secara tidak langsung memiliki peran dalam pemberian opini going concern pada suatu perusahaan (Sulistya dan Sukartha, 2013). 
Keberadaan komisaris independen dalam perusahaan diharapkan mampu menyeimbangkan proses pengambilan keputusan terkait dengan perlindungan terhadap pihak pemegang saham minoritas dan stakeholder lainnya (Sulistya dan Sukartha, 2013). Semakin banyak dewan komisaris independen maka semakin besar pengawasan yang dilakukan oleh dewan komisaris independen. Adanya pengawasan yang semakin efektif maka akan mempengaruhi kinerja manajer perusahaan. Kinerja manajer yang semakin meningkat akan mempengaruhi laba perusahaan, sehingga akan mempengaruhi pemberian opini audit going concern (Eduk dan Nugraeni, 2015).

Untuk menghindari adanya kecurangan dalam pelaporan keuangan maka BAPEPAM mewajibkan emiten atau perusahaan publik untuk memiliki komite audit. Komite audit merupakan komite yang dibentuk oleh Dewan Komisaris untuk melakukan tugas pengawasan pengelolaan perusahaan. Komite audit berfungsi untuk meningkatkan kualitas laporan keuangan dan meningkatkan fungsi audit internal dan eksternal (Tandungan dan Mertha, 2016). Adanya komite audit, pengendalian dan pengawasan menjadi lebih detail dan kuat oleh karena itu diharapkan keuangan yang dihasilkan menjadi berkualitas dan wajar dengan adanya komite audit disuatu perusahaan. (Sulistya dan Sukartha, 2013).

Telah banyak penelitian yang dilakkan guna mengetahui faktor-faktor apa saja yang mempengaruhi penerimaan opini audit going concern beberapa diantaranya yaitu penelitian yang dilakukan oleh Krissindiastuti dan Rasmini (2016) ,Muttaqin dan Sudarno (2012), dan Nursari dan Maria (2015) menunjukkan bahwa Opinion shopping berpengaruh pada pemberian opini audit going concern. Namun berbeda dengan hasil penelitian Kartika (2012) yang menyatakan bahwa opinion shopping tidak berpengaruh terhadap pemberian opini audit going concern. Penelitian sebelumnya yang dilakukan oleh Kartika (2012) dan Nursari dan Maria (2015) menunjukkan bahwa pertumbuhan perusahaan berpengaruh terhadap pemeberian opini audit going concern. Namun berbeda dengan penelitian Sulistya dan Sukartha (2013) dan Krissindiastuti dan Rasmini (2016) yang menyatakan bahwa pertumbuhan perusahaan tidak berpengaruh terhadap penerimaan opini audit going concern.Penelitian sebelumnya yang dilakukan oleh Saifudin dan Trisnawati (2016) menunjukkan bahwa likuditas berpengaruh terhadap pemberian opini audit going concern. Namun berbeda dengan penelitian Muttaqin dan Sudarno, yang menyataka bahwa likuiditas tidak berpengaruh terhadap penerimaan opini audit going concern.Penelitian sebelumnya oleh Eduk dan Nugraeni (2015) menyatakan bahwa proporsi komisaris independen berpengaruh terhadap penerimaan opini aduit going concern.Namun berbeda dengan penelitian Sulistya dan Sukartha (2013) yang menyatakan proporsi komisaris independen tidak berpengaruh terhadap penerimaan opini audit going concern.Penelitian sebelumya oleh Susanti dan Bunandi (2014) menyatakan bahwa komite audit berpengaruh terhadap penerimaan opini audit going concern.Namun berbeda dengan penelitian Tandungan dan Mertha (2016) yang melakukan penelitian menggunakan keberadaan komite audit sebagai salah satu variabel independennya dan dihasilkan bahwa keberadaan komite audit tidak berpegnaruh terhadap penerimaan opini audit going concern.

Adanya ketidakkonsistenan penelitianpenelitian sebelumnya sehingga mendorong peneliti untuk menguji kembali tentang pengaruh opinion shopping, pertumbuhan perusahaan, likuditas, komposisi komisaris independen dan komite audit terhadap penerimaan opini audit going concern. Perbedaan penelitian ini dengan penelitian sebelumnya adalah pada perusahaan yang diteliti yaitu perusahaan real estate dan property. Serta perbedaan dalam tahun penelitian yang akan diteliti yaitu tahun 2013-2015.

Berdasarkan beberapa paparan dan penjelasan diatas, maka penulis memilih judul " DETERMINAN OPINI AUDIT GOING CONCERN (Studi Empiris pada Perusahaan Real Estate dan Property yang terdaftar di BEI tahun 2013-2015)".

\section{Kajian Pustaka dan Pengembangan Hipotesis Kajian Pustaka Agency Theory (Teori Keagenan)}

Teori keagenan (Agency theory) merupakan basis teori yang mendasari praktik bisnis perusahaan yang dipakai selama ini.Teori tersebut berakar dari sinergi teori ekonomi, teori keputusan, sosiologi, dan teori organisasi. Prinsip utama teori ini menyatakan adanya hubungan kerja antara pihak yang memberi 
wewenang (prinsipal) yaitu investor dengan pihak yang menerima wewenang (agensi) yaitu manajer, dalam bentuk kontrak kerja sama yang disebut "nexus of contract" (Muttaqin dan Sudarno, 2012). Dalam suatu perusahaan, konflik kepentingan antara prinsipal dengan agen salah satunya dapat timbul karena adanya kelebihan aliran kas (excess cash flow). Kelebihan arus kas cenderung diinvestasikan dalam hal-hal yang tidak ada kaitannya dengan kegiatan utama perusahaan. Ini menyebabkan perbedaan kepentingan karena pemegang saham lebih menyukai investasi yang berisiko tinggi yang juga menghasilkan return tinggi, sementara manajemen lebih memilih investasi dengan risiko yang lebih rendah.

Perbedaan "kepentingan ekonomis" ini bisa saja disebabkan ataupun menyebabkan timbulnya informasi asymmetri (Kesenjangan informasi) antara pemegang saham (Stakeholders) dan prinsipal.Manajer dapat menggunakan keleluasaan yang dimilikinya untuk memanipulasi laporan keuangan agar kinerjanya terlihat baik di mata pemegang saham.Sebaliknya pemegang saham menginginkan informasi yang sesungguhnya mengenai kinerja manajemen untuk menilai apakah manajemen telah bertindak sesuai kehendak pemegang saham atau tidak (Gama dan Astuti, 2014).

\section{Opini Audit}

Dalam melakukan penugasan umum, auditor ditugasi memberikan opini atas laporan keuangan perusahaan. Menurut standar profesional akuntan publik SA Seksi 110, tujuan audit atas laporan keuangan oleh auditor independen pada umumnya adalah untuk menyatakan pendapat tentang kewajaran dalam semua hal yang meterial, posisi keuangan, hasil usaha, perubahan ekuitas,dan arus kas sesuai dengan prinsip akuntansi yang berlaku umum di Indonesia. Pendapat atau opini audit merupakan bagian yang tidak terpisahkan dari laporan audit. Laporan audit penting sekali dalam suatu audit atau proses atestasi lainnya karena laporan tersebut menginformasikan pemakai informasi tentang apa yang dilakukan auditor dan kesimpulan yang diperolehnya (Aridika dan Ekayani, 2013).

\section{Opini Audit Going Concern}

Dalam SPAP (2011) kelangsungan hidup (going concern) suatu perusahaan merupakan ketidakmampuan suatu usaha saat jatuh tempo untuk melunasi hutang-hutangnya tanpa melakukan penjualan atas aktiva yang dimiliki, melakukan restrukturisasi utang, serta melakukan pemaksaan dari luar sebagai usaha perbaikan operasi perusahaan. Auditor dalam memberikan opini audit harus berdasarkan kondisi perusahaan yang sesungguhnya sebagai bentuk tanggungjawabnya ke publik yang memanfaatkan hasil opini audit tersebut. Sehingga diharapkan opini audit tidak memberikan informasi yang merugikan dan menyesatkan bagi pengguna laporan keuangan, seperti para investor yang akan membuat keputusan berinvestasi (Nursari dan Maria, 2015). Hal ini dikarenakan, pemberian opini going concern auditor menandakan adanya keraguan akan kemampuan perusahaan mempertahankan kelangsungan hidup entitasnya dalam waktu dekat (Sulistya dan Sukartha, 2013).

Secara umum, beberapa hal yang dapat mempengaruhi auditor dalam menerbitkan opini audit going concern (IAI, 2001: seksi 341.3 paragraf 6) antara lain:

1. Tren negatif, sebagai contoh: Kerugian operasi yang terjadi berulang, kekurangan modal kerja, arus kas yang negatif, rasio keuangan yang tidak baik.

2. Petunjuk lain tentang kemungkinan kesulitan keuangan perusahaan, sebagai contoh : Kegagalan dalam memenuhi kewajiban, penunggakan pembayaran dividen, penjualan sebagian besar aktiva.

3. Masalah intern, sebagai contoh: Pemogokan tenaga kerja, ketergantungan besar atas kesuksesan proyek tertentu, komitmen jangka panjang yang bersifat tidak ekonomis, kebutuhan untuk memperbaiki operasi.

4. Masalah luar yang terjadi, sebagai contoh : Pengaduan gugatan pengadilan, keluarnya undang-undang atau masalah lain yang kemungkinan membahayakan kemampuan entitas untuk beroperasi, kehilangan pemasok atau pelanggan, kerugian akibat bencana alam.

\section{Opinion Shopping}

Opinion shopping didefinisikan oleh SEC, sebagai aktivitas mencari auditor yang mau mendukung perlakuan akuntansi yang diajukan oleh manajemen untuk mencapai tujuan pelaporan 
perusahaan, walaupun menyebabkan laporan tersebut menjadi tidak reliable.Perushaan yang berhasil dalam opinion shopping melakukan pergantian audior dengan harapan mendapat unqualified opinion dari auditor baru karena opini qualified cenderung dihindari dan kurang disukai oleh klien (Krissindiastuti dan Rasmini, 2016). Perusahaan biasanya menggunakan pergantian auditor (Auditor Switching) untuk menghindari penerimaan opini going concern dalam dua cara (Teoh, 1992) dalam Muttaqin dan Sudarno (2012. Pertama, jika auditor bekerja pada perusahaan tertentu, perusahaan dapat mengancam melakukan pergantian auditor. Kedua, bahkan ketika Auditor tersebut independen, perusahaan akan memberhentikan Akuntan Publik (Auditor) yang cenderung memberikan opini going concern atau sebaliknya akan menunjuk auditor yang cenderung memberikan opini non going concern. Argumen ini disebut opinion shopping.Tujuan pelaporan dalam opinion shopping dimaksudkan untuk meningkatkan (memanipulasi) hasil operasi atau kondisi keuangan perusahaan.

\section{Pertumbuhan Perusahaan}

Pertumbuhan perusahaan sering dipakai sebagai tolak ukur dalam menilai perkembangan suatu perusahaan.Dalam dunia bisnis, pengertian pertumbuhan menunjukan semakin meningkatnya ukuran dan aktivitas perusahaan dalam jangka panjang. Banyak cara untuk mengukur pertumbuhan perusahaan, antara lain kenaikan penjualan dan kenaikan aktiva.

Pertumbuhan perusahaan menunjukkan pertumbuhan kekuatan perusahaan dalam industry dan mengindikasikan kemampuan perusahaan dalam mempertahankan kelangsungan usahanya (Kartika, 2012). Perusahaan yang mengalami pertumbuhan berarti perusahaan tersebut mampu meningkatkan volume penjualannya dibandingkan tahun-tahun sebelumnya. Penjualan yang meningkat menunjukkan aktivitas operasional perusahaan berjalan dengan semestinya (Ardik dan Ekayani, 2013). Sehingga semakin tinggi rasio pertumbuhan penjualan auditee, akan semakin kecil kemungkinan auditor untuk menerbitkan opini audit going concer (Krissindiastuti dan Rasmini, 2016).

\section{Likuiditas}


yang independen dapat membantu mengurangi tekanan menajemen untuk mendapatkan opini wajar tanpa pengecualian (unqualified) pada saat auditor merasa benar untuk mengeluarkan opini audit going concern. Sehingga semakin besar proporsi komite audit maka semakin kecil kemungkinan pemberian opini audit terkait masalah kelangsungan hidup suatu perusahaan kedepannya.

\section{Pengembangan Hipotesis \\ Pengaruh Opinion Shopping Terhadap Penerimaan OpiniAudit Going Concern \\ Opinion shopping didefinisikan oleh SEC,} sebagai aktivitas mencari auditor yang mau mendukung perlakuan akuntansi yang diajukan oleh manajemen untuk mencapai tujuan pelaporan perusahaan, walaupun menyebabkan laporan tersebut menjadi tidak reliable. Perusahaan biasanya menggunakan pergantian auditor (Auditor Switching) untuk menghindari penerimaan opini going concern dalam dua cara (Teoh, 1992) dalam Muttaqin dan Sudarno (2012. Pertama, jika auditor bekerja pada perusahaan tertentu, perusahaan dapat mengancam melakukan pergantian auditor. Kedua, bahkan ketika Auditor tersebut independen, perusahaan akan memberhentikan Akuntan Publik (Auditor) yang cenderung memberikan opini going concern atau sebaliknya akan menunjuk auditor yang cenderung memberikan opini non going concern. Berdasarkan uraian di atas, maka dapat dirumuskan hipotesis sebagai berikut:

H1: Opinion shopping berpengaruh terhadap penerimaan opini audit going concern.

\section{Pengaruh Pertumbuhan Perusahaan Terhadap Penerimaan Opini Audit Going Concern}

Pertumbuhan perusahaan sering dipakai sebagai tolak ukur dalam menilai perkembangan suatu perusahaan. Dalam penelitian ini pertumbuhan perusahaan diproksikan dengan rasio pertumbuhan penjualan.Penjualan merupakan kegiatan operasi utama auditee. Auditee yang mempunyai rasio pertumbuhan penjualan yang positif mengindikasikan bahwa auditee dapat mempertahankan posisi ekonominya dan lebih dapat mempertahankan kelangsungan hidupnya.
Penjualan yang terus meningkat dari tahun ke tahun akan memberi peluang auditee untuk memperoleh laba. Semakin tinggi rasio pertumbuhan penjualan auditee, akan semakin kecil kemungkinan auditor untuk menerbitkan opini audit going concern (Krissindiastuti dan Rasmini, 2016). Berdasarkan uraian di atas, maka dapat dirumuskan hipotesis sebagai berikut:

H2: Pertumbuhan perusahaan berpengaruh terhadap penerimaan opini audit going concern.

\section{Pengaruh Likuiditas Terhadap Penerimaan Opini Audit Going Concern}

Likuiditas diartikan sebagai kemampuan perusahaan untuk membayar kewajiban jangka pendeknya.Semakin tinggi likuiditas yang dimiliki semakin besar pula kemampuan perusahaan dalam membayar kewajiban jangka pendeknya. Semakin rendah likuiditas semakin rendah pula kemampuan perusahaan dalam membayar kewajiban jangka pendennya (Saifudin dan Trisnawati, 2016). Perusahaan yang memiliki rasio likuiditas yang tinggi, menunjukkan kemampuannya dalam membayar hutang - hutang jangka pendeknya dengan tepat waktu, sehingga auditor tidak akan memberikan opini audit going concern pada perusahaan yang mampu menjalankan perusahaannya untuk periode selanjutnya (Melani dkk, 2016). Berdasarkan uraian di atas, maka dapat dirumuskan hipotesis sebagai berikut:

H3: Likuiditas berpengaruh terhadap penerimaan opini audit going concern.

\section{Pengaruh Proporsi Komisaris Independen Terhadap Penerimaan Opini Audit Going Concern}

Komisaris independen merupakan sebuah badan dalam perusahaan yang biasanya beranggotakan dewan komisaris yang independen yang berasal dari luar perusahaan yang berfungsi untuk menilai kinerja perusahaan secara luas dan keseluruhan (Puspitasari dan Rustiana, 2014). Keberadaan komisaris independen di dalam perusahaan diharapkan mampu menjamin transparansi laporan keuangan perusahaan serta mengawasi kepatuhan perusahaan terhadap peraturan yang berlaku. Sehingga semakin besar proporsi komisaris independen akan mengurangi kemungkinan pemberian opini audit going concern (Setiawan 2011 dalam Sulistya dan Sukartha, 2013). 
Berdasarkan uraian di atas, maka dapat dirumuskan hipotesis sebagai berikut:

H4: Proporsi komisaris independen berpengaruh terhadap penerimaan opini audit going concern.

\section{Pengaruh Komite Audit Terhadap Penerimaan Opini Audit Going Concern}

Komite audit merupakan komite yang dibentuk oleh Dewan Komisaris untuk melakukan tugas pengawasan pengelolaan perusahaan. Komite audit berfungsi untuk meningkatkan fungsi audit internal dan eksternal serta meningkatkan kualitas laporan keuangan (Tandungan dan Mertha, 2016). Semakin banyak anggota komite audit yang dimiliki, perusahaan akan dapat meningkatkan kualitas laporan keuangan dan fungsi audit internal dan eksternal. Tentunya hal ini dapat mendukung kegiatan operasional yang pada akhirnya juga akan berimplikasi pada terjaganya kelangsungan hidup (going concern) perusahaan (Devi dan Badera, 2016). Berdasarkan uraian diatas, maka dapat dirumuskan hipotesis sebagai berikut:

H5:Komite audit berpengaruh terhadap pemenberian opini audit going concern.

\section{Metode Penelitian}

\section{Jenis Penelitian}

Penelitian ini merupakan jenis penilitian kuantitatif dengan melakukan uji hipotesis.yang telah disusun terhadap variabel-variabel penelitian sekunder, karena dilakukan dengan mengambil sampel dari suatu populasi yang menerbitkan publikasi atas data-data yang dibutuhkan dalam penelitian ini.

\section{Jenis Data dan Sumber Data}

Data yang digunakan dalam penelitian ini adalah data sekunder.Dalam penelitian ini yang menjadi data sekunder adalah annual report dari perusahaan real estate dan property yang terdaftar di Bursa Efek Indonesia pada periode 2013-2015.Data sekunder yang digunakan diperoleh dari situs resmi BEI www.idx.co.id.

\section{Populasi dan Sampel Penelitian}

Populasi dalam penelitian ini adalah perusahaan real estate dan property yang terdaftar di Bursa Efek Indonesia (BEI) periode 2013-2015.Sampel dalam penelitian ini diambil dengan teknik Purposive
Sampling, yaitu metode penentuan sampel dengan pertimbangan tertentu. Sampel yang dipilih memiliki kriteria sebagai berikut:

1. Perusahaan real estate dan property yang terdaftar di BEI tahun 2013-2015

2. Perusahaan real estate yang mengeluarkan laporan keuangan auditan berturut-turut selama periode 2013-2015

3. Perusahaan mengungkapkan informasi tentang variabel yang diteliti

\section{Metode Pengumpulan Data}

Teknik yang digunakan untuk mengumpulkan data dalam penelitian ini adalah dokumentasi, yaitu dengan cara mengumpulkan, mencatat, dan mengkaji data sekunder yang berupa laporan keuangan auditan perusahaan yang dipublikasikan oleh BEI melaluiwww.idx.co.id.

\section{Definisi Operasional dan Pengukuran Variabel Opini Audit Going Concern (Y)}

Variabel dependen dalam penelitian ini adalah opini audit going concern. Kelangsungan hidup (going concern) suatu perusahaan merupakan ketidakmampuan suatu usaha saat jatuh tempo untuk melunasi hutang-hutangnya tanpa melakukan penjualan atas aktiva yang dimiliki, melakukan restrukturisasi utang, serta melakukan pemaksaan dari luar sebagai usaha perbaikan operasi perusahaan (SPAP, 2011). Perhitungan variabel dependen yaitu opini audit going concern dengan menggunakan pengukuran variabel dummy. Perusahaan yang menerima opini audit going concern diberi kode 1 sedangkan yang mendapat opini nongoing concern diberi kode 0 (Rasmini, 2016).

\section{Opinion Shopping $\left(\mathrm{X}_{1}\right)$}

Opinion shopping didefinisikan oleh SEC, sebagai aktivitas mencari auditor yang mau mendukung perlakuan akuntansi yang diajukan oleh manajemen untuk mencapai tujuan pelaporan perusahaan, walaupun menyebabkan laporan tersebut menjadi tidak reliable.Opinion shopping diukur dengan $0=$ Perusahaan yang tidak melakukan pergantian auditor, dan $1=$ untuk perusahaan yang melakukan pergantian auditor (Muttaqin dan Sudarno, 2012). 


\section{Pertumbuhan Perusahan $\left(\mathbf{X}_{2}\right)$}

Rudyawan dan Badera (2009) dalam Wulandari (2014) menyatakan pertumbuhan perusahaan

Pertumbuhan Penjualan $=\frac{(\text { Penjualan Bersiht }- \text { Penjualan Bersiht } \mathrm{t}-1)}{\text { Penjualan Bersih } \mathrm{t}-1}$ mengindikasikan kemampuan perusahaan dalam mempertahankan kelangsungan usahanya.Perusahaan yang memiliki pertumbuhan aktiva lancar kemungkinan perusahaan tersebut sedang mengalami pertumbuhan, yang menandakan bahwa perusahaan mampu menjaga going concern usahanya.Pengukuran pertumbuhan perusahaan didasarkan pada penelitian Kartika (2012) dengan menggunakan rasio pertumbuhan penjualan auditee. Pertumbuhan perusahaan dirumuskan sebagai berikut:

\section{Likuiditas ( $\left.\mathbf{X}_{\mathbf{3}}\right)$}

Likuiditas adalah kemampuan perusahaan dalam memenuhi kewajiban jangka pendeknya. Jika perusahaan memiliki likuiditas (diproksi dengan current ratio) yang baik, maka kemungkinan untuk dapat meneruskan aktivitas usahanya akan lebih besar, sehingga kemungkinan untuk memperoleh opini going concern akan lebih sedikit (Muttaqin dan Sudarno, 2012). Pengukuran likuditas diproksikan dengan current ratio:

$$
\text { Likuiditas }=\frac{\text { Aktiva Lancar }}{\text { Kewajiban Lancar }}
$$

\section{Proporsi Komisaris Independen $\left(\mathbf{X}_{4}\right)$}

Menurut KNKG (2006) Dewan Komisaris sebagai organ perusahaan bertugas dan bertanggungjawab secara kolektif untuk melakukan pengawasan dan memberikan nasihat kepada Direksi serta memastikan bahwa Perusahaan melaksanakan GCG. Tingginya pengawasan yang dilakukan oleh dewan komisaris independen akan meningkatkan kinerja perusahaan sehingga akan mempengaruhi going concern suatu perusahaan (Eduk dan Nugraeni, 2015). Pengukuran proporsi komisaris independen didasarkan penelitian Adjani dan Rahardja (2013) dalam Eduk dan Nugraeni (2015) yang dihitung dengan presentase komisaris independen dalam dewan komisaris.

$$
K I=\frac{\text { Jumlah Komisaris Independen }}{\text { Jumlah Dewan Komisaris }}
$$

Riset Akuntansi dan Keuangan Indonesia, 3(1), 2018

\section{Komite Audit ( $\left.\mathbf{X}_{5}\right)$}

Komite audit merupakan komite yang dibentuk oleh Dewan Komisaris untuk melakukan tugas pengawasan pengelolaan perusahaan. Ramadhany (2004) dalam Sulistya dan Sukartha (2013) menyatakan komite audit yang independen dapat membantu mengurangi tekanan menajemen untuk mendapatkan opini wajar tanpa pengecualian (unqualified) pada saat auditor merasa benar untuk mengeluarkan opini audit going concern. Sehingga semakin besar proporsi komite audit maka semakin kecil kemungkinan pemberian opini audit terkait masalah kelangsungan hidup suatu perusahaan kedepannya. Pengukuran komite audit didasarkan pada penelitian Sulistya dan Sukartha (2013) dengan presentase jumlah anggota komite audit dibagi jumlah dewan komisaris.

$$
K A=\frac{\text { Jumlah Komite Awdit }}{\text { Jumlah Dewan Komisaris }}
$$

\section{Metode Analisis Data}

Pengujian hipotesis dalam penelitian ini dilakukan dengan menggunakan analisis multivariate dengan menggunakan regresi logistik (logistic regression).Variabel independen dalam regresi logistik merupakan campuran antara variabel kontinyu (metrik) dan kategorial (non metrik) (Ghozali, 2011).

Pada penelitian ini regresi logistic digunakan untuk mengguji pengaruh prior opinion, opinion shopping, pertumbuhan perusahaam, proporsi komisaris independen dan komite audit terhadap penerimaan opini audit going concern. Adapun model regresi logistik pada penelitian ini adalah sebagai berikut:

$\mathrm{OGC}=\alpha+\beta 1 P O+\beta 2 O S+\beta 3 P P+\beta 4 K I+\beta 5 K A+$

$$
\varepsilon
$$

\section{Pengukuran Variabel}

1. OGC $=$ Opini auditor, diukur dengan variabel dummy yaitu angka 0 untuk opini non going concern dan angka 1 untuk opini audit going concern.

2. $\mathbf{O S}=$ Opinion Shopping dihitung dengan perusahaan yang tidak melakukan pergantian auditor diberi nilai 0 , se dangkan untuk perusahaan yang melakukan pergantian auditor diberi nilai 1 . 
3. $\mathbf{P P}=$ Pertumbuhan perusahaan dihitung dengan rasio pertumbuhan penjualan auditee.

4. $\mathbf{L}=$ Pengukuran Likuiditas dihitung menggunakan quick ratio.

. KI= Proporsi komisaris independen diuk dengan presentase komisaris independ dalam dewan komisaris

6. $\mathbf{K A}=$ Variabel ini diukur dengan melit jumlah anggota di audit.

Keterangan:
$\boldsymbol{\alpha}=$ Konstanta
$\varepsilon=$ error

audit.Hasil descriptive statistics variabel independent dengan program SPSS 24 dapat dilihat dalam tabel 2.

\section{Tabel 2}

Hasil Analisis Statistik Deskriptif

\begin{tabular}{|l|c|c|c|c|c|}
\hline \multicolumn{1}{|c|}{ Variabel } & $\mathrm{N}$ & Minimum & Maximum & Mean & Std. Deviation \\
\hline OS & 120 & 0 & 1 & 0,1833 & 0,38856 \\
\hline PP & 120 & 0,08 & 7,77 & 1,0103 & 0,79523 \\
\hline LI & 120 & 0,001 & 59,71 & 3,31964 & 6,228782 \\
\hline KI & 120 & 0,17 & 1 & 0,3821 & 0,11097 \\
\hline KA & 120 & 0,14 & 1 & 0,5255 & 0,17811 \\
\hline OGC & 120 & 0 & 1 & 0,0417 & 0,20066 \\
\hline
\end{tabular}

Sumber: Data sekunder yang diolah, 2017.

\section{Hasil dan Pembahasan Deskripsi sampel}

Populasi yang digunakan dalam penelitian ini adalah perusahaan-perusahaan real estate dan propertyyang terdaftar di Bursa Efek Indonesia (BEI) periode 2013-2015.Metode pengambilan sampel yang digunakan dalam pengumpulan data adalah metode purposive sampling yaitu metode pengambilan sampel yang dilakukan sesuai dengan tujuan penelitian yang telah ditetapkan. Kriteria-kriteria yang ditetapkan untuk pemilihan sampel dapat dilihat pada tabel dibawah ini:

Tabel 1

Kriteria Pengambilan Sampel

\begin{tabular}{|c|l|c|}
\hline & \multicolumn{1}{|c|}{ Keterangan } & Jumlah \\
\hline & Populasi: & 141 \\
\hline $\begin{array}{l}\text { Perusahaan real estate dan property yang terdaftar di BEI selama periode } \\
2013-2015\end{array}$ & $\begin{array}{l}\text { Perusahaan real estate dan property yang tidak mengeluarkan laporan } \\
\text { keuangan auditan berturut-turut selama periode tahun 2013-2015 }\end{array}$ \\
\hline & $\begin{array}{l}\text { Perusahaan yang tidak mengungkapkan informasi tentang variabel yang } \\
\text { diteliti }\end{array}$ & $(3)$ \\
\hline & \begin{tabular}{l} 
Sampel yang memenuhi kriteria selama 3 tahun \\
\multicolumn{1}{|c|}{ Total sampel penelitian }
\end{tabular} \\
\hline & \multicolumn{1}{|c}{120} \\
\hline
\end{tabular}

Sumber: Data sekunder yang diolah, 2017.

\section{Analisis Statistik Deskriptif}

Statistik deskriptif memberikan gambaran atau deskripsi suatu data yang terlihat dari nilai rata-rata (mean), standar deviasi, varian, maksimum, minimum, sum, range, kurtosis dan skewness (kemencengan distribusi). Variabel independen dalam penelitian ini adalah opinion shopping, pertumbuhan perusahaan, likuiditas, proporsi komisaris independen dan komite

Riset Akuntansi dan Keuangan Indonesia, 3(1), 2018
Berdasarkan Tabel 2 menunjukkan hasil statistik deskriptif dari masing-masing variabel penelitian. Bedasarkan table tersebut, hasil statistic deskriptif terhadap variabel opinion shoppingmemiliki nilai minimum sebesar 0 yang artinya bahwa dalam pengukuran variabel opinion shopping, perusahaan yang menjadi sampel tidak melakukan opinion shopping. Sedangkan nilai maksimumnya sebesar 1 , artinya bahwa dalam pengukuran variabel opinion shopping, perusahaan yang menjadi sampel melakukan opinion shopping. Nilai rata-rata sebesar 0,1833 yang mendekati 0 , menunjukkan bahwa sebagian besar perusahaan yang menjadi penelitian tidak melakukan opinion shopping. Sedangkan standar deviasi sebesar 0.38856, hal ini menunjukkan bahwa ukuran penyebaran dari variabel opinion shopping adalah sebesar 38,8\% dari 40 perusahan yang diteliti.

Berdasarkan hasil statistik deskriptif terhadap variabel pertumbuhan perusahaanmemiliki nilai minimum sebesar 0,08 yang artinya bahwa dalam pengukuran variabel pertumbuhan perusahaan, perusahaan yang menjadi sampel tidak mengalami pertumbuhan perusahaan dan nilai maksimum sebesar 7,77 artinya, dalam pengukuran variabel pertumbuhan perusahaan, perusahaan yang menjadi sampel mengalami pertumbuhan perusahaan. Nilai rata-rata sebesar 1,0103menunjukkan bahwa sebagian besar perusahaan yang menjadi penelitian tidak mengalami pertumbuhan perusahaan. Sedangkan standar deviasi sebesar 0,79523, hal ini menunjukkan bahwa ukuran penyebaran dari variabelpertumbuhan perusahaan adalah sebesar 79,5\% dari 40 perusahan yang diteliti.

Berdasarkan hasil statistik deskriptif terhadap variabel likuiditasmemiliki nilai minimum sebesar 
0,001 yang artinya bahwa dalam pengukuran variabel likuiditas, perusahaan yang menjadi sampel tidak bisa memenuhi kewajiban jangka pendek.dan nilai maksimum sebesar 59.71 artinya, dalam pengukuran variabel likuiditas, perusahaan yang menjadi sampel dapat memenuhi kewajiban jangka pendek. Nilai ratarata sebesar 3,31964 menunjukkan bahwa sebagian besar perusahaan yang menjadi penelitian tidak dapat memenuhi kewajiban jangka pendek, Sedangkan standart deviasi sebesar 6.228782, hal ini menunjukkan bahwa ukuran penyebaran dari variabellikuiditas adalah sebesar $622,8 \%$ dari 40 perusahan yang diteliti.

Berdasarkan hasil statistik deskriptif terhada variabel proporsi komisaris independenmemiliki nilai minimum sebesar 0,17 yang artinya dalam pengukuran variabel proporsi komisaris independen, perusahaan yang menjadi sampel memiliki proporsi komisaris independen yang kecil dan nilai maksimum sebesar 1 artinya, dalam pengukuran variabel proporsi komisaris independen, perusahaan yang menjadi sampel memiliki proporsi komisaris independen yang besar. Nilai rata-rata sebesar 0,3821 menunjukkan bahwa sebagian besar perusahaan yang menjadi penelitian sampel memiliki proporsi komisaris independen yang kecil. Sedangkan standar deviasi sebesar 0,11097, hal ini menunjukkan bahwa ukuran penyebaran dari variabelproporsi komisaris independen adalah sebesar $11,09 \%$ dari 40 perusahan yang diteliti.

Berdasarkan hasil statistik deskriptif terhadap variabel komite audit memiliki nilai minimum sebesar 0,14 yang artinya dalam pengukuran variabel komite audit, perusahaan yang menjadi sampel memiliki jumlah komite audit yang kecil dan nilai maksimum sebesar 1 artinya, dalam pengukuran variabel komite audit perusahaan yang menjadi sampel memiliki jumlah komite audit yang besar. Nilai rata-rata sebesar 0,5255 menunjukkan bahwa sebagian besar perusahaan yang menjadi penelitian memiliki jumlah komite audit yang kecil. Sedangkan standar deviasi sebesar 0,20066, hal ini menunjukkan bahwa ukuran penyebaran dari variabelpertumbuhan perusahaan adalah sebesar $20 \%$ dari 40 perusahan yang diteliti.

\section{Uji Kelayakan Model Regresi}

Kelayakan model regresi dinilai dengan menggunakan Hosmer and Lemeshow"s Goodness of Fit Test. Model ini untuk menguji hipotesis nol bahwa data empiris sesuai dengan model (tidak ada perbedaan antara model dengan data sehingga model dapat dikatakan fit). Jika Nilai statistik Hosmer and Lemeshow"s Goodness of Fit Test lebih besar dari 0,05, maka hipotesis nol tidak dapat ditolak dan berarti model mampu memprediksi nilai observasinya atau dapat dikatakan bahwa model dapat diterima karena sesuai dengan data observasinya (Ghozali, 2011:341). Berikut adalah hasil penelitian dengan menggunakan program SPSS 24.0 diperoleh output tabel IV.3.

Tabel 3

Hasil Analisis Uji Kelayakan Model Regresi

\begin{tabular}{|l|l|l|l|}
\hline NilaiChi Square & Df & Sig. & Keterangan \\
\hline & 8 & 1 & Model diterima (Model Fit) \\
\hline
\end{tabular}

Sumber: Data sekunder yang diolah, 2017

Tampilan output SPSS pada tabel menunjukkan bahwa besarnya nilai statistik Hosmer and Lemeshow Goodness of Fit sebesar 0,531dengan probabilitas signifikansi 1 lebih besar dari 0,05 maka dapat disimpulkan bahwa hipotesis nol tidak dapat ditolak yang berarti bahwa model mampu memprediksi nilai observasinya atau dapat dikatakan bahwa model diterima (model fit) karena sesuai dengan data observasinya.

\section{Uji Keseluruhan Model (Overall Model Fit)}

Statistik yang digunakan berdasarkan pada fungsi likelihood.LikelihoodL terdiri dari model adalah probabilitas bahwa model yang dihipotesiskan menggambarkan data input. Adanya pengurangan nilai antara $-2 \log \mathrm{L}$ awal (initial -2LL function) dengan nilai -2 Log $\mathrm{L}$ pada langkah berikutnya menunjukkan bahwa model yang dihipotesiskan fit dengan data. Berikut hasil penelitian dengan menggunakan program SPSS versi 24.0 diperoleh output sebagai berikut:

\section{Tabel 4}

Hasil Analisis Perbandingan Nilai -2 Log L

\begin{tabular}{|l|l|}
\hline Keterangan & Nilai -2 Log L \\
\hline Block Number $=0$ (Awal) & 41,569 \\
\hline Block Number $=1$ (Akhir) & 24,571 \\
\hline
\end{tabular}

Sumber: Data sekunder yang diolah, 2017

Berdasarkan Tabel diatas menunjukkan bahwa dapat dilihat dari nilai statistic -2 Log L yaitu tanpa variabel hanya konstan saja sebesar 41,569setelah dimasukkan 5 variabel baru yang ditunjukkan tabel IV.4 maka nilai -2 Log L turun menjadi 24,571 atau terjadi penurunan sebesar16,998. Penurunan ini 
signifikan atau tidak dapat dibandingkan dengan df (selisih df dengan konstan saja dan df dengan 5 variabel independen). Df1 $=(n-k) 120$ dan df2 $=120$ $5=115$, jadi selisih df $=120-115=5$. Berdasarkan tabel percentage points of the $t$ distribution dengan $\mathrm{df}=5$ didapat angka 2,571 Oleh karena 16,998 lebih besar dari nilai tabel (2,571), maka dapat dikatakan bahwa selisih penurunan -2 Log L signifikan. Hasil ini berarti penambahan opinion shopping, pertumbuhan perusahaan, likuiditas, proporsi komisaris independen dan komite audit kedalam model memperbaiki model.

\section{Koefisien Determinasi (Nagelkarke $R$} Square)

Nagelkarke $R$ Square merupakan modifikasi dari koefisien Cox dan Snell $R$ Square untuk memastikan bahwa nilaiinya bervariasi dari 0 (nol) sampai 1 (satu). Hal ini dilakukan dengan cara membagi nilai Cox dan Snell $R$ Square dengan nilai maksimumnya. Nilai Negelkerke $R$ Square dapat diinterpretasikan seperti nilai $\mathrm{R}^{2}$ pada multiple regression. Berikut hasil penelitian dengan menggunakan program SPSS versi 24.0 diperoleh output sebagai berikut:

\section{Tabel 5}

Hasil Analisis Koefisien Determinasi (Nagelkarke R Square)

\begin{tabular}{|l|l|l|}
\hline $\begin{array}{l}-2 \quad \text { Log } \\
\text { Likehood }\end{array}$ & $\begin{array}{l}\text { Nilai Cox \& Snell } R \\
\text { Square }\end{array}$ & $\begin{array}{l}\text { Nilai } \\
\text { Nagelkarke } R \\
\text { Square }\end{array}$ \\
\hline $24,571^{\mathrm{a}}$ & 0,132 & 0,451 \\
\hline
\end{tabular}

Sumber: Data Sekunder yang diolah, 2017

Dilihat dari output SPSS pada tabel menunjukkan bahwa nilai Cox Snell R Square sebesar 0,132 dan nilai Nagelkerke $\mathrm{R}^{2}$ adalah 0,451 . Hasil ini berarti bahwa variabilitas variabel dependen (sustainability report) yang dapat dijelaskan oleh variabilitas variabel independen (opinion shopping, pertumbuhan perusahaan, likuiditas, proporsi komisaris independen dan komite audit) sebesar $45,1 \%$.

\section{Pengujian Hipotesis}

Tabel 6

Hasil Uji Model Regresi Logistik

\begin{tabular}{|l|r|r|r|r|r|l|}
\hline Variabel & B & S.E & Wald & df & Sig. & Keterangan \\
\hline OS & 0,521 & 1,435 & 0,132 & 1 & 0,717 & Ditolak \\
\hline PP & 2,195 & 1,245 & 3,106 & 1 & 0,078 & Ditolak \\
\hline LI & $-3,675$ & 1,409 & 6,804 & 1 & 0,009 & Diterima \\
\hline KI & $-4,247$ & 8,975 & 0,224 & 1 & 0,636 & Ditolak \\
\hline
\end{tabular}

Sumber: Data Sekunder yang diolah, 2017

Berdasarkan tabel 6 dapat diketahui persamaan regresi logistik dalam penelitian ini adalah sebagai berikut:

$$
\begin{gathered}
\mathrm{GC}=-2,087+0,5210 \mathrm{~S}+2,195 \mathrm{PP}-3,675 \mathrm{LI}- \\
4,247 \mathrm{KI}+4,157 \mathrm{KA}+\varepsilon
\end{gathered}
$$

Berdasarkan persamaan regresi diatas, menunjukkan bahwa:

a. Nilai konstanta -2,087 dengan arah negatif. Hal ini menunjukkan bahwa apabila variabel opinion shopping, pertumbuhan perusahaan, likuiditas, proporsi komisaris independen dan komite audit tidak berubah atau konstan, maka opini audit going concern akan menurun sebesar 2,087.

b. Nilai koefisien regresi untuk variabel opinion shopping adalah sebesar 0,521 dengan arah koefisien positif. Hal ini dapat diartikan bahwa setiap adanya peningkatan sebesar satu pada opinion shopping maka opini audit going concernakan meningkat sebesar 0,521.

c. Nilai koefisien regresi untuk variabel pertumbuhan perusahaan adalah sebesar 2,195 dengan arah koefisien positif. Hal ini dapat diartikan bahwa setiap adanya peningkatan sebesar satu pada pertumbuhan perusahaan maka opini audit going concern akan meningkat sebesar 2,195.

d. Nilai koefisien regresi untuk variabel likuiditas adalah sebesar -3,675 dengan arah koefisien negatif. Hal ini dapat diartikan bahwa setiap adanya peningkatan sebesar satu pada likuiditas maka opini audit going concern akan menurun sebesar 3,675.

e. Nilai koefisien regresi untuk variabel proporsi komisaris independen adalah sebesar -4,247 dengan arah koefisien negatif. Hal ini dapat 
diartikan bahwa setiap adanya peningkatan sebesar satu pada proporsi komisaris independen maka opini audit going concern akan menurun sebesar 4,247.

f. Nilai koefisien regresi untuk variabel komite audit adalah sebesar 4,157 dengan arah koefisien positif. Hal ini dapat diartikan bahwa setiap adanya peningkatan sebesar satu pada komite audit maka opini audit going concern akan meningkat sebesar 4,157.

\section{Uji Hipotesis}

Kriteria pengujian dengan tingkat kepercayaan yang digunakan adalah 95\% atau taraf signifikansi 5\% $(\alpha=0,05)$. Apabila nilai signifikansi kurang dari 0,05 maka hipotesis diterima, jika tingkat signifikansi lebih besar dari 0,05 maka hipotesis tidak dapat diterima.

\section{Pengaruh Opinion Shopping terhadap Penerimaan Opini Audit Going Concern}

Berdasarkan hasil penelitian menunjukkan bahwa nilai koefisien regresi sebesar 0,521 dengan signifikansi sebesar 0,717 lebih besar dari 0,05, maka H1 ditolak, artinya opinion shopping tidak berpengaruh terhaap penerimaan opini audit going concern.

\section{Pengaruh Pertumbuhan Perusahaan terhadap Penerimaan Opini Audit Going Concern}

Berdasarkan hasil penelitian menunjukkan bahwa nilai koefisien regresi sebesar 2,195 dengan signifikansi sebesar 0,078 lebih besar dari 0,05, maka H2 ditolak, artinya pertumbuhan perusahaantidak berpengaruh terhaap penerimaan opini audit going concern.

\section{Pengaruh Likuiditas terhadap Penerimaan Opini Audit Going concern}

Berdasarkan hasil penelitian menunjukkan bahwa nilai koefisien regresi sebesar -3,675 dengan signifikansi sebesar 0,009 lebih kecil dari 0,05, maka H3 diterima, artinya likuditas berpengaruh terhaap penerimaan opini audit going concern.

\section{Pengaruh Proporsi Komisaris Independen terhadap Penerimaan Opini Audit Going Concern \\ Berdasarkan hasil penelitian menunjukkan bahwa nilai koefisien regresi sebesar $-4,247$ dengan}

signifikansi sebesar 0,636 lebih besar dari 0,05, maka H4 ditolak, artinya proporsi komisaris independentidak berpengaruh terhaap penerimaan opini audit going concern.

\section{Pengaruh Komite Audit terhadap Penerimaan Opini Audit Going Concern}

Berdasarkan hasil penelitian menunjukkan bahwa nilai koefisien regresi sebesar 4,157 dengan signifikansi sebesar 0,262 lebih besar dari 0,05, maka H5 ditolak, artinya komite audittidak berpengaruh terhaap penerimaan opini audit going concern.

\section{Pembahasan \\ Pengaruh Opinion Shopping terhadap Penerimaan Opini Audit Going Concern \\ Pengujian terhadap variabel opinion shopping} menunjukkan bahwa nilai signifikansi sebesar 0,717 yaitu lebih besar dari alpha sebesar 5\% (0,05), hasil tersebut menunjukkan bahwa hipotesis (H1) ditolak, berarti opinion shoppingtidak berpengaruh terhadap penerimaan opini audit going concern. Hasil penelitian ini menunjukkan bahwa opinion shopping tidak memengaruhi auditor dalam memberikan opini audit going concern. Perusahaan yang melakukan pergantian auditor tidak meningkatkan penerimaan opini audit going concern, sebaliknya perusahaan yang tidak melakukan pergantian auditor juga tidak semakin menurunkan penerimaan opini audit going concern.Hal ini terjadi karena auditor mempunyai independensi. Sehingga meskipun perusahaan melakukan pergantian auditor ataupun tidak melakukan pergantian auditor, ketika auditor tersebut independen maka tidak akan berpengaruh terhadap tingkat penerimaan opini audit going concern.

Penelitian ini mendukung hasil penelitian yang dilakukan oleh Kartika (2012) yang menyatakan bahwa opinion shopping tidak berpengaruh terhadap penerimaan opini audit going concern.

\section{Pengaruh Pertumbuhan Perusahaan terhadap Penerimaan Opini Audit Going Concern \\ Pengujian terhadap variabel pertumbuhan perusahaanmenunjukkan bahwa nilai signifikansi sebesar 0,078 yaitu lebih besar dari alpha sebesar 5\%}


$(0,05)$, hasil tersebut menunjukkan bahwa hipotesis (H2) ditolak, berarti pertumbuhan perusahaantidak berpengaruh terhadap penerimaan opini audit going concern. Hal ini disebabkan karena pertumbuhan penjualan tidak diikuti dengan peningkatan saldo laba dan penurunan beban hutang. Peningkatan beban operasional yang lebih tinggi dibandingkan dengan peningkatan penjualan akan mengakibatkan laba bersih setelah pajak yang negatif dan selanjutnya akan berdampak pada berkurangnya saldo laba ditahan. Tidak ada jaminan bahwa perusahaan yang mengalami peningkatan pada penjualan bersihnya juga akan mengalami peningkatan pada laba bersihnya. Auditor akan lebih mempertimbangkan kemampuan perusahaan untuk menghasilkan laba dalam memberikan opini audit going concern.

Penelitian ini mendukung hasil penelitian yang dilakukan oleh Sulistya dan Sukartha (2012) dan Krissindiastuti dan Rasmini (2016) yang menyatakan bahwa pertumbuhan perusahaantidak berpengaruh terhadap penerimaan opini audit going concern.

\section{Pengaruh Likuiditas terhadap Penerimaan Opini Audit Going Concern}

Pengujian terhadap variabel

likuiditasmenunjukkan bahwa nilai signifikansi sebesar 0,009 yaitu lebih kecil dari alpha sebesar 5\% $(0,05)$, hasil tersebut menunjukkan bahwa hipotesis (H3) diterima, berarti likuiditas berpengaruh terhadap penerimaan opini audit going concern. Hal ini mengidinkasikan bahwa tinggi rendahnya tingkat kemampuan perusahaan untuk menutupi semua kewajiban jangka pendeknya dengan menggunakan aktiva lancar yang dimiliki oleh perusahaan berpengaruh signifikan terhadap pengeluaran opini audit going concern. Semakin tinggi tingkat likuiditas, semakin kecil kemungkinan dikeluarkannya opini audit going concern, dan juga sebaliknya.

Penelitian ini mendukung hasil penelitian yang dilakukan oleh Saifudin dan Trisnawati (2016) dan Ariesetywan dan Rahayu (2015) yang menyatakan bahwa likuiditas berpengaruh terhadap penerimaan opini audit going concern.

\section{Pengaruh Proporsi Komisaris Independen terhadap Penerimaan Opini Audit Going Concern}

Pengujian terhadap variabel proporsi komisaris independenmenunjukkan bahwa nilai signifikansi sebesar 0,636 yaitu lebih besar dari alpha sebesar 5\% $(0,05)$, hasil tersebut menunjukkan bahwa hipotesis (H4) ditolak, yang berarti proporsi komisaris independen tidak berpengaruh terhadap penerimaan opini audit going concern. Hasil ini mengindikasikan bahwa proporsi komisaris independen tidak mempengaruhi auditor dalam memberikan opini audit going concern. Tidak terdapat pengaruh antara komposisi komisaris independen pada usaha mengurangi kemungkinan pemberian opini going concern, kemungkinan karena keberadaan komisaris independen telah diatur dalam pedoman umum good corporate governance dan Peraturan Bapepam-LK Nomor IX.I.5, yang menyatakan bahwa perusahaan publik wajib memiliki sekurang-kurangnya satu orang komisaris independen. Sehingga berdasarkan hasil observasi, jumlah proporsi komisaris independen tidak ada perbedaan yang berarti dan tidak berpengaruh terhadap peningkatan atau perbaikan kondisi posisi keuangan perusahaan. Selain itu, Bapepam tidak membedakan tugas dan tanggung jawab komisaris independen dari dewan komisaris lainnya.Sehingga adanya komisaris independen tidak memberikan dampak yang signifikan bagi perusahaan. Karena hal inilah yang mungkin menyebabkan auditor kurang mempertimbangkan komposisi komisaris independen ketika akan memberi opini audit mengenai going concern pada auditee.

Penelitian ini mendukung hasil penelitian yang dilakukan oleh Chandra (2013) dan Rahardja (2013) yang menyatakan bahwa proporsi komisaris independen tidak berpengaruh terhadap penerimaan opini audit going concern.

\section{Pengaruh Komite Audit terhadap Penerimaan Opini Audit Going Concern}

Pengujian terhadap variabel proporsi komite auditmenunjukkan bahwa nilai signifikansi sebesar 0,262 yaitu lebih besar dari alpha sebesar $5 \%(0,05)$, hasil tersebut menunjukkan bahwa hipotesis (H5) ditolak, yang berarti komite audit tidak berpengaruh terhadap penerimaan opini audit going concern. Hasil ini dapat diindikasikan bahwa ukuran komite audit kurang mampu menunjang efektivitas kinerja dari komite audit, posisi komite audit masih sebatas untuk memenuhi peraturan dan persyaratan pencatatan perusahaan di bursa. Hal ini dapat disebabkan karena tanggung jawab komite audit yaitu kepada dewan 
komisaris bukan kepada pihak manajemen perusahaan. Sehingga komite audit tidak dapat terlibat langsung dalam penyelesaian masalah keuangan/operasional perusahaan dan menegur secara langsung bila terdapat. Hasil penelitian ini dapat menjadi suatu sinyal bagi komite audit agar dapat membatu dewan komisaris dengan lebih efektif, misalnya dalam memastikan struktur pengendalian internal perusahaan dilaksanakan dengan baik. Sebab meskipun hampir semua perusahaan telah memiliki komite audit, masih banyak perusahaan yang menerima opini audit mengenai going concern.

Penelitian ini mendukung hasil penelitian yang dilakukan oleh Tandungan dan Mertha (2016) dan Sulistya dan Sukartha, (2013) yang menyatakan bahwa komite tidak berpengaruh terhadap penerimaan opini audit going concern.

\section{Simpulan}

Hasil penelitian menunjukan bahwa variabel likuiditas berpengaruh signifikan terhadap penerimaan opini audit going concern. Sedangkan variabel opinion shopping, pertumbuhan perusahaan, proporsi komisaris independen dan komite audit tidak berpengaruh signifikan terhadap penerimaan opini audit going concern.

Keterbatasan pada penelitian ini yaitu Jumlah sampel perusahaan yang dijadikan objek penelitian terbatas pada perusahaan real estate dan property yang terdaftar pada Bursa Efek Indonesia, sehingga hasil penelitian tidak dapat digeneralisasi untuk semua jenis perusahaan. Skala tahun pengambilan data yang terbatas dari tahun 2013-2015, sehingga tidak mencerminkan hasil penelitian yang mutlak pada semua periode laporan keuangan. Penggunaan variabel dalam penelitian ini hanya ada 5, yaitu: opinion shopping, pertumbuhan perusahaan,likuiditas, proprosi komisaris independen, dan komite audit. Variabel yang menunjukkan adanya pengaruh signifikan terbatas pada faktor likuiditas.

Berdasarkan beberapa keterbatasan yang telah disampaikan peneliti sebelumnya, maka saran untuk peneliti selanjutnya adalah diharapkan memperluas sampel perusahaan tidak hanya dalam perusahaan real estate dan property saja, misalnya seluruh perusahaan yang terdaftar di BEI.Sehingga diperoleh daya generalisasi hasil penelitian yang lebih besar.Peneliti selanjutnya diharapkan menambahkan interval tahun pengambilan data menjadi misalnya 10 tahun. Di harapkan juga peneliti selanjutnya menggunakan faktor lain dalam menguji pengaruh terhadap opini audit going concern, seperti: audite tenure, opini audit tahun sebelumnya, kepemilikan manajerial dan lain sebagainya.

\section{Referensi}

[1] Ardika, I Kadek dan Ni Nengah Seri Ekayani (2013). Analisis Faktor-Faktor yang Mempengaruhi Kecenderungan Penerimaan Opini Audit Going Concern pada Perusahaan Manufaktur Yang Terdaftar Di BEI Periode 2007-2011.Jurnal Ilmiah Akuntansi dan Humanika JINAH Volume 3 No.1 Singaraja.

[2] Ariesetiawan, Aldy dan Sri Rahayu (2015). Pengaruh Profitabilitas, likuiditas, dan Pertumbuhan Perusahaan Terhadap Penerimaan Opini Audit Modifikasi Going Concern (Studi Pada Perusahaaan Sektor Transportasi yang Terdaftar di BEI periode 2009-2013). EProceeding of Management, Vol.2, No.1.

[3] Astuti, Retnno Irtani dan Darsono (2012). Pengaruh Faktor Keuangan dan Non Keuangan Terhadap Penerimaan Opini Audit Going Concern. DIPONEGORO JOURNAL OF ACCOUNTING, Volume 1, Nomor 2, Halaman $1-10$.

[4] Azzizah Rizki dan Indah Anisykurlillah (2014). Pengaruh Ukurang Perusahaan, Debt Default, dan Kondisi Keuangan Perusahaan Terhadap Penerimaan Opini Audit Going Concern.Accounting Analysis Journal.

[5] Chandra, Felicia Liana (2013). Pengaruh Penerapan Good Corporate Governance Terhadap Opini Audit Mengenai Going Concern pada Perusahaan yang Terdaftar dalam Bursa Efek Indonesia Periode 2010-2011. Jurnal Ilmiah Mahasiswa Universitas Surabaya, Vol.2 No. 1.

[6] Eduk, Kristina Deventy dan Nugraeni (2015). Pengaruh Mekanisme Corporate Governance Terhadap Pemberian Opini Audit Going Concern (Studi Empiris pada Perusahaan Manufaktur yang Terdaftar di Bursa Efek Indonesia Tahun 20112013). JRAMB, Prodi Akuntansi, Fakultas Ekonomi, UMB Yogyakarta Volume 1.

[7] Gama Angga Patria dan Sri Astuti (2014). Analisis Faktor-Faktor Penerimaan Opini Auditor dengan Memodifikasi going Concern 
(Studi Empiris di Bursa Efek Indonesia). Jurnal Ilmiah Akuntansi dan Bisnis, Vol.9 No.1.

[8] Ghozali, Imam. (2011). Aplikasi Analisis Multivariate Dengan Program IBM SPSS 19 (edisi kelima). Semarang: Badan Peneribit Universitas Diponegoro.

[9] Ghozali, Imam. 2006. Aplikasi AnalisisMultivariate dengan SPSS. Semarang: Badan Penerbit Universitas Diponegoro.

[10] Ikatan Akuntansi Indonesia (2011). Standar Profesional Akuntan Publik. Jakarta: Salemba empat.

[11]Kartika, Andi (2012). Pengaruh Kondisi Keuangan dan Non Keuangan Terhadap Penerimaan Opini Audit Going Concern pada Perusahaan Manufaktur di BEI. Dinamika Akuntansi, Keuangan dan Perbankan, Hal: 25 40.

[12] Komite Nasional Kebijakan Good Corporate Governance (KNKG).2006. Pedoman Umum Good Corporate Governance (GCG).

[13] Krissdiastuti, Monicadan Ni Ketut Rasmini(2016), Faktor-Faktor yang Mempengaruhi Opini Audit Going Concern. Ejurnal Akuntansi Universitas Udayana Vol.14.1, 451-481.

[14]Melania, Sutra, Rita Andini dan Rina Arifati (2016). Analisis Pengaruh Kualitas Auditor, Likuiditas, Profitabilitas, Solvabilitas, dan Ukuran Perusahaan Terhadap Opini Audit Going Concern pada Perusahaan Manufaktur yang Terdaftar di Bursa Efek Indonesia. Journal of Accounting, Volume 2 No.2.

[15] Muttaqin, Ariffandita Nuri dan Sudarno (2012). Analisis Pengaruh Rasio Keuangan Dan Faktor Non Keuangan Terhadap Penerimaan Audit Going Concern.DIPONEGORO JOURNAL OF ACCOUNTING, Volume 1, Nomor 2, Halaman 1-13.

[16] Nurdin, Nurul Nisah, Dudi Pratomo dan Dedik Nur Triyanto (2016). Pengaruh Struktur Kepemilikan dan Likuiditas Terhadap Penerimaan Opini Audit Modifikasi Going Concern (Studi Kasus Pada Perusahaan Manufaktur yang Terdaftar di Bursa Efek Indonesia Periode 2010-2015).Journal Eproc Telkom University.
[17] Nursari, Enggar dan Evi Maria (2015). Pengaruh Audit Tenure, Opinion Shopping, Leaverage dan Pertumbuhan Perusahaan Terhadap Penerimaan Opini Audit Going Concern Pada Perusahaan Perbankan dan Pembiayaan yang Go Public Di Bursa Efek Indonesia. Jurnal JIBEKA Volume 9 Nomor, 37-43.

[18] Puspitasari, Anastasia Sally dan Rustiana (2013). Pengaruh Proporsi Dewan Komisaris Independen, Kepemilikan Manajerial dan Kepemilikan Iinstitusional Terhadap Pemberian Opini Audit Going Concern. Universitas Atma Jaya Yogyakarta, 1-14.

[19]Rahardja, Ema Diandra Adjani Surya (2013). Analisis Pengaruh Corporate Governance Terhadap Kemungkinan Pemberian Opini Audit Going Concern Oleh Auditor Independen (Studi Empiris Pada Perusahaan Manufaktur yang Terdaftar di BEI Tahun 2009-2011). DIPONEGORO JOURNAL OF ACCOUNTING, Volume 2 Nomer 2, 2337-3806.

[20] Sulistya, Ayu Febri dan Pt. Dyan Yaniartha Sukartha (2013). Pengaruh Prior Opinion, Pertumbuhan dan Mekanisme Corporate Governance Pada Pemberian Opini Audit Going Concern. E-Jurnal Akuntansi Universitas Udayana 5.1, 17-32.

[21] Susanti, Yuli dan Bunandi (2014). Analisa Faktor-Faktor yang Mempengaruhi Penerimaan Opini Audit Going Concern. Journal of Accounting \& Management Research Vo.9 No 1.

[22] Saifudin, Aris dan Rina Trisnawati (2016). Pengaruh Ukuran Perusahaan, Profitabilitas, Likuiditas, Solvabilitas dan Pertumbuhan Terhadap Opini Audit Going Concern (Studi Empiris pada Perusahaan Manufaktur yang Terdapat di Bursa Efek Indonesia Tahun 20112014). Syariah Paper Accounting FEB UMS.

[23] Tandungan, Debby dan I Made Mertha (2016). Pengaruh Komite Audit, Ukurang Perusahaan, Audit Tenure, dan Reputasi KAP Terhaap Opini Audit Going Concern. E-Jurnal Akuntansi Universitas Udayana Vol.16.1, 45-71.

[24] Verdiana, Komang Anggita dan I Made Karya Utama (2013). Pengaruh Reputasi Auditor, Disclosure, Audit Client Tenure, Pada Kemungkinan Pengungkapan Opini Audit Going 
Concern.E-Jurnal Akuntansi Universitas Udayana 5.3, 530-543.

[25] Wulandari, Soliyah (2014). Analisis FaktorFaktor yang Mempengaruhi Auditor dalam Memberikan Opini Audit Going Concern. EJurnal Akuntansi Universitas Udayana 6.3, 531558. 